\title{
PERLINDUNGAN HUKUM BAGI PELAKU USAHA TRANSPORTASI ONLINE DALAM INDUSTRI 4.0
}

\author{
Muhamad Arif Fahmi ${ }^{1}$, Ahmad Munir ${ }^{2}$, Ainul Masruroh ${ }^{3}$ \\ ${ }^{1,2,3}$ Universitas Islam Darul 'Ulum \\ 1'farif4944@gmail.com, ${ }^{2}$ ahmadmunir@unisda.ac.id, ${ }^{3}$ ainul@unisda.ac.id
}

\begin{abstract}
In Indonesia, the last five years is very rapid development of technology until it penetrated into the field of transportation called online transportation. The existence of online transportation is hypothesized by most people as a positive part of the evolution of Industry 4.0 in the field of transportation in Indonesia. Not a few people also look negatively at this online transportation, because the existence of online transportation is considered to displace the existence of conventional transportation and the impact of income from conventional transportation is decreasing. The need for legal protection against online transportation businesses and conventional transportation must be provided by the government. This research is a normative research that examines regulations related to transportation and legal protection of online transportation businesses. Then there needs to be a role from the government to provide a legal umbrella on this online transportation.
\end{abstract}

Keywords: Legal Protection, Online Transportation, Industry 4.0.

\begin{abstract}
ABSTRAK
Di Indonesia, lima tahun terakhir ini sangat pesat perkembangan teknologi sampai sampai merambah ke bidang transportasi yang dinamakan transportasi online. Keberadaan transportasi online dihipotesiskan oleh sebagian besar masyarakat sebagai hal yang positif dari evolusi Industri 4.0 dalam bidang transportasi di Indonesia. Tidak sedikit masyarakat juga memandang negatif transportasi online ini, karena keberadaan transportasi online ini dianggap menggusur keberadaan transportasi konvensional dan berdampak penghasilan dari transportasi konvensional ini semakin menurun. Perlu adanya perlindungan hukum terhadap pelaku usaha transportasi online maupun transportasi konvensional harus diberikan oleh pemerintah. Penelitian ini merupakan penelitian normatif yang mengkaji peraturan terkait transportasi dan perlindungan hukum terhadap pelaku usaha transportasi online. Maka perlu adanya peran dari pemerintah untuk memberi payung hukum tentang transportasi online ini.
\end{abstract}

Kata Kunci: Perlindungan Hukum, Transportasi Online, Industri 4.0. 


\section{PENDAHULUAN}

Ilmu pengetahuan dan teknologi (IPTEK) berkembang sangat pesat, hal itu menjadikan pembangunan menjadi lebih maju dan cepat. Penemuan ilmiah dibidang IPTEK telah mempercepat dari fase satu ke fase berikutnya. Fase pertumbuhan IPTEK dapat terjadi dalam beberapa fase yakni, fase pertama pra organis, proses penguasaan bersumber pada alam akan tetapi belum mengambil bentuk sehingga kehidupan manusia dari hasil pemberian alam. Fase kedua yakni agraris, manusia mulai mengenal pembudidayaan alam dengan cara membuat alatalat seperti roda, kincir air dan berbagai alat lain untuk membantu dalam bidang pertanian, pembudidayaan ternak untuk transportasi dan cadangan untuk makanan. Fase ketiga yakni industri, sudah lahirnya teknologi informasi dan IPTEK menuju kesempurnaan, otomatisasi telah dilengkapi dengan robotisasi, rekayasa genetika sudah memasuki tahap revolusi dan tumbuhnya teknologi ramah lingkungan manusia untuk menyejahterakan kehidupannya. ${ }^{1}$

Di Indonesia sendiri dampak dari perkembangan teknologi digital telah merambah sampai di bidang transportasi, karena dirasa sangat nyaman dan mudah diakses maka membuat transportasi online ini sangat mudah melebarkan sayapnya sampai penjuru kota di nusantara. Di sini perlu tidakan pemerintah untuk memberikan perisai hukum bagi para pelaku usaha transportasi online, Seiring berjalannya waktu perusahaan perusahaan transportai online di Indonesia ini saling bersaing untuk menjadi yang terbaik dari yang baik, disinilah peran pemerintah sangat dibutuhkan, khususnya peran dari Komisi Pengawas Persaingan Usaha (KPPU). Dengan semakin banyaknya perusahaan transportasi online di Indonesia khususnya ojek online, maka pemerintah membuat keputusan untuk menetapkan batas bawah dan atas pada tarif ojek online. ${ }^{2}$

Keberadaan transportasi online yang dianggap sebagian besar masnyarakat satu hal yang positif dari evolusi transportasi di Indonesia, namun tidak sedikit

\footnotetext{
${ }^{1}$ Abdul Manan, Aspek-Aspek Pengubah Hukum, Kencana, Jakarta, Cetakan ke-4, April 2013, h. 171. Disitir dalam Aria Dimas Harapan, Hukum Dan Teklogi Suatu Kajian Teoritis Terhadap Penomena Layanan Transfortasi Online, Surya Kencana Dua: Dinamika Masalah Hukum dan Keadilan, Vol. 6 No. 1, Maret 2016, h. 21. Online-qNxB52
} 
masyarakat memandang negatif transportasi online ini, karena keberadaan transportasi online ini dianggap menggusur keberadaan transportasi konvensional dan berdampak penghasilan dari transportasi konvensional ini semakin menurun. Dan banyaknya minat di bidang transportasi online ini khususnya bagi para masyarakat yang belum memiliki pekerjaan memilih menjadi driver ojek online, karena syaratnya sangat mudah dan sederhana, dapat dipastikkan dalam jangka waktu lima sampai sepuluh tahun kedepan jika pemerintah tidak membatasi penggunaan transportasi online ini maka sudah dapat dipastikan Indonesia akan mengalami kemacetan yang sangat luar biasa, maka dari itu sangat perlu dibutuhkan peran aktif pemerintah.

\section{METODELOGI}

Penelitian normatif digunakan dalam peneletian untuk menemukan bentuk perlindungan hukum terahadap pelaku usaha transportasi online. Pendekatan yang digunakan berupa pendekatan konseptual yang meliputi perlindungan hukum dan transportasi online. Selanjutnya pendekatan perundang-undangan dilakukan dengan cara menelaah ketentuan perundang-undangan yang berkaitan dengan peraturan mengenai lalu lintas, transportasi, dan perlindungan hukum.

\section{PEMBAHASAN}

Penganut aliran hukum alam menyatakan tujuan hukum adalah untuk mewujudkan keadilan. Hukum ada dan diadakan untuk mengatur dan menciptakan keseimbangan atau harmonisasi kepentingan manusia. Namun dalam perkembangan dan kenyataannya, keadilan bukanlah satu-satunya istilah yang digunakan untuk menunjukkan tujuan hukum pasca keteraturan. Di dalam suatu negara hukum yang berbentuk negara hukum modern (welfare state), tujuan hukum adalah untuk mewujudkan kesejahteraan bagi rakyat. ${ }^{3}$

Konsep negara kesejahteraan (welfare state) berkembang pada abad 19 dari proses kausalitas konsep political state dan legal state, dimana negara memegang peranan yang sangat besar dalam pembuatan dan pelaksanaan policy. Konsep negara kesejahteraan mengharuskan negara melaksanakan kegiatannya untuk membangun kesejahteraan masyarakat sehingga negara diberikan kewenangan

${ }^{3}$ Lili Rasyidi \& Wyasa Putra, Hukum Sebagai Suatu Sistem, Cet II; Mandar Maju, Bandung, 2003, h. 184-185. 
untuk melakukan campur tangan dalam berbagai kegiatan manusia, ${ }^{4}$ terutama dalam melindungi pihak yang lemah ${ }^{5}$

Di bidang ekonomi campur tangan negara dalam perekonomian pasar adalah untuk meningkatkan kesejahteraan umum dan memaksimumkan kesejahteraan sosial sehingga memperkecil dampak kegagalan pasar terhadap masyarakat dan kekeliruan terhadap berbagai sumber daya, ${ }^{6}$ Mereka yang kurang beruntung dalam bersaing mestilah diberikan perlindungan tertentu. Sebab prinsip persaingan yang sangat bebas tidak memperhitungkan nilai kemanusiaan. Oleh karena itu peranan pemerintah yang lebih besar sangat dibutuhkan untuk mengantisipasi ketidakadilan tersebut, sehingga peranan hukum dalam bisnis menjadi semakin penting. ${ }^{7}$

Sepanjang sejarah perkembangan perekonomian, terdapat tolak tarik antara pasar yang harus diatur (oleh pemerintah) di satu pihak dengan pasar yang bebas (free market) di lain pihak. Manakala suatu pasar harus diatur, maka pengaturannya didasari argumen bahwa memang dalam hal-hal tertentu pemerintah harus mengintervensi pasar antara lain dengan pengaturan tentang persaingan usaha, pemberian subsidi, pemberian government loan, dan sensor untuk kegiatan tertentu. Kekuasaan pemerintah untuk pasar ini bersumber dari kekuasaan yang disebut power of economic regulation. ${ }^{8}$ Dalam free market pasar akan langsung mengoreksi jika terdapat hal tidak diinginkan akibat persaingan bebas lewat apa yang disebut oleh Adam Smith invisible hand, dimana jika ada pihak yang tidak sanggup bertahan dalam kompetisi mereka harus mundur, karena alam akan menyeleksinya. Dalam kenyataanya teori tersebut tidak dapat diikuti dalam praktek di Negara manapun ${ }^{9}$ bahkan the invisible hand digantikan dengan the visible hand yakni h. 11-12.

${ }^{4}$ Moh. Mahfud. MD, Demokrasi Dan Konstitusi Di Indonesia, Rineka Cipta, Jakarta, 2003,

${ }^{5}$ Jimly Asshidiqqie, Pergeseran Kekuasaan Legislatif dan Eksekutif, Universitas Indonesia, 2000, h. 97.

${ }^{6}$ Robert E; Gordin, Reason for Welfare; economic; Social and political but Ultimately Moral, Dalam Responsibility Right \& Welfare; the Theory of Welfare State;Westview Press Inc; Colorado, 1988, h. 22. Seperti dikutip oleh Putu Sudarma, Implementasi Pengaturan Larangan Praktek Monopoli dan Persaingan Usaha Tidak Sehat, Disertasi tidak diterbitkan; Universitas Airlangga, Surabaya, 2000, h. 24

John Maynard Keynes, seperti dikutip oleh Munir Fuady, Hukum Anti Monopoli Menyongsong Era Persaingan Sehat, Citra Adytia Bakti; Bandung, 2003, h. 24-29

${ }^{8}$ Munir Fuady, Hukum Anti Monopoli, Citra Aditya Bakti, Bandung, 2000, h. 23.

${ }^{9}$ Ibid., h. 24. 
berupa ikut campurnya pemerintah lewat perundang-undangan tertentu untuk memastikan bahwa kompetisi pasar berjalan seperti yang diharapkan.

Menurut Munir Fuady ${ }^{10}$ yang menjadi alasan utama mengapa pasar perlu untuk diatur secara yuridis adalah ;secara moral ;Prinsip moral bagaimanapun harus dipertimbangkan termasuk dalam berbisnis, perwujudan prinsip moral dalam bisnis antara lain dilakukan dengan intervensi pemerintah terhadap pasar. Adapun secara yuridis konstitusional intervensi pemerintah atas pasar diperbolehkan lewat pasal 33 UUD NRI 1945 yang menentukan bahwa perekonomian disusun atas usaha bersama berdasarkan atas asas kekeluargaan.

Sejalan dengan hal tersebut Seotandyo menegaskan di negara berkembang ekonomi dikembangkan berdasarkan planned economy yang berfungsi melaksanakan rencana pembangunan pemerintah tidak berdasarkan mekanisme pasar (market economy), dalam perkembangannya fungsi hukum dalam planned economy aktifitas ekonomi tidak secara penuh dikuasai hukum, ${ }^{11}$ sehingga untuk dapat menciptakan struktur pasar yang kompetitif diperlukan suatu undang-undang persaingan usaha, sebagai alat untuk mengendalikan prilaku pelaku usaha yang merugikan masyarakat konsumen, merusak perkembangan dunia usaha dan bahkan merugikan Negara dalam bentuk beban fiskal, dalam kaitannya dengan ekonomi makro, tujuan utama suatu undang-undang persaingan usaha adalah mengurangi sampai sekecil mungkin penderitaan masyarakat (welfare cost) dalam suatu perekonomian nasional. $^{12}$

Perlindungan terhadap rakyat (rechtssbescherming van de burgers tegen de overheid/legal protection of the individual in relation to acts of administrative authorities) merupakan konsep yang didasarkan pada konsep negara hukum yang menempatkan pengakuan dan perlindungan terhadap hak asasi manusia sebagai titik sentral, sedangkan bagi Indonesia yang menjadi titik sentral perlindungan hukum adalah hak asasi yang terdapat dalam Pancasila, ${ }^{13}$ sehingga prinsip perlindungan hukum bagi rakyat Indonesia adalah prinsip perlindungan terhadap

\footnotetext{
${ }^{10}$ Ibid., h. 22-30.

${ }^{11}$ Soetandyo Wignjoseobroto, Hukum, Paradigma, Metode dan Masalahnya, Cet I, Elsan \& Huma, Jakarta, 2002, h. 294-296.

${ }^{12}$ Bambang P Adiwiyoto, Konsep dasar Persaingan Usaha Tidak Sehat, Prossiding. 2005, h. 124.

${ }^{13}$ Philipus M Hadjon, Perlindungan Hukum Bagi Rakyat Indonesia, Bina Ilmu; Surabaya, 1987, h. 84-85.
} 
harkat dan martabat manusia yang bersumber pada Pancasila dan prinsip negara hukum yang berdasarkan Pancasila. ${ }^{14}$. Oleh karena itu perlindungan terhadap rakyat Indonesia diarahkan pada:

a. Usaha untuk mencegah terjadinya sengketa atau sedapat mungkin mengurangi terjadinya sengketa

b. Usaha untuk menyelesaikan sengketa (hukum ) dengan musyawarah

c. Penyelesaian sengketa melalui peradilan merupakan jalan terakhir.

Perlindungan hukum sendiri terbagi menjadi perlindungan hukum represif dan preventif yaitu perlindungan hukum yang bertujuan untuk mencegah terjadinya sengketa, sebaliknya perlindungan hukum represif bertujuan untuk menyelesaikan sengketa ${ }^{15}$. Pemenuhan terhadap hak asasi manusia harus dilakukan sebagai bentuk tanggung jawab negara. ${ }^{16}$ Dalam hal ini pengaturan untuk meminimalisir terjadinya persaingan curang dan menciptakan persaingan yang sehat diperlukan sebagai pengejawantahan konsep perlindungan hukum dan negara hukum Pancasila yang bertujuan untuk mencapai kesejahteraan bersama seperti rumusan sila kelima keadilan sosial bagi seluruh rakyat Indonesia. ${ }^{17}$ Pengaturan persaingan usaha melaksanakan public welfare dan efisiensi untuk kesejahteraan masyarakat. ${ }^{18}$

Fidel Miro menjabarkan transportasi merupakan suatu usaha menggerakkan, mengangkut, mengalihkan atau berpindahnya suatu objek dari suatu tempat asal ke tempat yang dituju ata yang di inginkan, dimana tempat yang di inginkan ini lebih memiliki niai fubgsional atau berguna untuk tujuan-tujuan yang diinginkan. ${ }^{19}$ Dari pengertian diatas dapat kia jabarkan yang dinamakan objek yaitu berupa orang ataupun barang yang memiliki fungsi untuk merubah posisi suatu objek ke tempat yang diinginkan atau lebih bermanfaat. Ada tiga pembagian di bidang transportasi, yaitu transportasi laut, transportasi darat dan transportasi udara. Dari pengertian online diatas dapat dijabarkan yang disebut transportasi online adalah sebuat

\section{${ }^{14}$ Ibid., h. 20.}

${ }^{15}$ Ibid., h. 2.

16 Muhammad Lutfi Hardiyanto, Shalahudin Serba Bagus, Ahmad Munir, "Hak Politik Mantan Narapidana Untuk Mencalonkan Diri Sebagai Calon Kepala Daerah (Analisis terhadap Putusan MK. No. 42/PUU-XIII/2015)”, Mimbar Yustitia, Vol. 1 No. 2, 2017, h. 114.

${ }^{17}$ Ibid., h. 65.

${ }^{18}$ Prosiding UU No. 5/1999 dan KPPU. Catatan Diskusi konsep dasar Persainganusaha tidak sehat dan pendekatan rule of reason dan per se dalam hukum persaingan.

19 Fidel Miro, Perencanaan Transportasi untuk mahasiswa: perencana dan praktisi, Erlangga, Jakarta, 2005, h. 4. 
taransaksi yang pelayananya menggunakanjasa transportasi yang berbasis online atau internet, mulai dari pemantauan jalur, distribusi, pembayaran dan evaluasi terhadap pelayanan jasa itu sendiri.

Fenomena transportasi online tersebut seolah menjadi oasis angkutan umum yang belum maksimal dalam pelayanannya. Sebagai solusi dari belum maksimalnya jasa angkutan umum maka transportasi online dalang sebagai alternatif dari akses kendaraan umum. Dari segi keselamatan, Undang-Undang Nomor 22 tahun 2009 tentang Lalu Lintas dan Angkutan Jalan ${ }^{20}$ menyatakan sepeda motor memang tidak tercantum sebagai sarana transportasi publik karena tidak layak. Namun sepeda motor sangat dibutuhkan jika dilihat dari aspek kebutuhan masyarakat, baik ojek konvensional maupun ojek berbasis online. selain melayani antar jemput penumpang (Goride), Go-Jek adalah perusahaan penyedia jasa yang bergerak dalam bidang teknologi dan transportasi berbasis online, Go-Jek juga melayani pemesanan makanan (Go-Food), pengiriman barang (Go-Send) dan beberapa layanan jasa lainnya. Terbukanaya lapangan kerja baru mrnjadi pengemudi Go-Jek untuk mengurangi angka pengangguran dan kemiskina di Indonesia merupakan latar belakang kehadiran Go-Jek . Tapi tanpa disadari dengan memudahkan persyaratan menjadi driver Go-Jek maka sama saja menanam benih benih kemacetan di jalan raya dan laka lantas di jalan raya.

Tarif yang transparan dengan cara pembayaran yang mudah, informasi driver yang bias diketahui, rute perjalanan yang dapat dipantau melalui aplikasi GoJek pada smartphone dan fasilitas gratis berupa penutup kepala dan masker yang harus di tawarkan oleh driver Go-Jek, itu semua merupakan keunggulan dari jasa transportasi berbasis teknologi informasi atau online. Dalam hal persaingan usaha, kehadiran Go-Jek menimbulkan kontroversi khususnya yang berkaitan dengan jasa transportasi ojek pangkalan atau biasa disebut ojek konvensional. Para driver ojek pangkalan memandang GO-JEK merupakan saingan berat dan dapat berdampak pada eksistensi mereka, meskipun cukup banyak dari mereka yang beralih menjadi driver Go-Jek. ${ }^{21}$ dan lagi lagi yang melatar belakangi adalah masalah ekonomi .

${ }^{20}$ Lembaran Negara Republik Indonesia Tahun 2009 Nomor 96, Tambahan Lembaran Negara Republik Indonesia Nomor 5025, selanjutnya disingkat UU Nomor 22 Tahun 2009.

${ }^{21}$ Geistiar Yoga Pratama, Suradi, Aminah, "Perlindungan Hukum Terhadap Data Pribadi Pengguna Jasa Transportasi Online Dari Tindakan Penyalahgunaan Pihak Penyedia Jasa 
didalam Undang-Undang Dasar Negara Republik Indonesia Tahun 1945 pasal 27 ayat 2 menyatakan bahwa "tiap tiap warganegara berhak atas pekerjaan dan penghidupan yang layak bagi kemanusiaan". Pada dasarnya setiap orang dapat menjalankan usaha secara mandiri.

Setiap perusahaan transportasi online ini Memberikan bonus bagi para driver drivernya, dalam memberikan bonus bagi para driver- drivernya melalui persyaratan-persyaratan tertentu. Bahkan dengan keuntungan usaha aplikasinya memberikan tambahan bagi konsumen dengan menyediakan asuransi kecelakaan oleh perusahaan asuransi yang bekerjasama dengan go-jek misalnya dengan Alianz. Bagi pemakai jasa go-jek dan go-car mendapat perlindungan asuransi kecelakaan. Keamanan transportasi online darat antara lain aplikasi menyediakan fitur-fitur dengan mendata seluruh driver, memonitor perjalanan para driver dan membantu melayani konsumen dengan mendisiplinkan para drivernya apabila mengecewakan seperti membatalkan melayani konsumen tanpa alasan yang dibenarkan. Perlindungan kepada konsumen tersebut terdapat dalam fitur-fitur aplikasi dalam transportasi darat online. Ini semua dilakukan guna bersaing dengan perusahaan transportasi online laninnya agar perusahaanya tidak kalah dengan yang lainnya, Kemajuan tekonologi informasi menawarkan software dari produk, pembuat software hanya tinggal pakai. Software tersebut yang dapat dijalankan oleh siapa saja dengan tawaran software yang efisien untuk sarana menjalankan usaha. Software dijalankan hanya oleh satu atau dua orang saja dengan kesitimewaan software yang ditawarkan tanpa harus membuat dengan susah payah. Fasilitas software tersebut termasuk fasilitas penyimpan data yang aman dan murah. Bentuk software tersbut dikenal dengan aplikasi "start-up". Memulai usaha dengan menggunakan software atau perangkat lunak penunjang yang telah tersedia dan efisien. Bentuk bentuk hubungan hukum antar subjek hukum yang dapat mengakibatkan secara hukum bervariasi. Model hubungan hukum transportasi online juga menunjukan perbedaan secara khas antara penyedia sarana elektronik, driver sebagai pihak yang memanfaatkan aplikasi dengan konsumen pengguna jasa transportasi online. Dengan adanya ini semua maka lebih merasa nyaman semua pihak yang mengunakan jasa transportasi ini. 
Pengaturan transportasi online harus mengacu kepada pengertian diatas padahal penyedia jasa angkutan online dalam hal ini driver adalah bersifat pribadi dan hanya memanfaatkan teknologi informasi dari penyelenggara elektronik dalam hal ini seperti Go-Jek atau go-Car dalam melakukan kontrak tidak tertulis dengan konsumen jasa angkutan on line. Tujuan dan asas dari Pasal 2 UU No. 22 Tahun 2009 dilakukan dengan memperhatikan beberapa asas tertentu antara lain: a. asas akuntabel; b. asas transparan; c. asas berkelanjutan; d. asas kemanfaatan; e. asas partisipatif; f. asas efektif dan efisien; g. asas terpadu; h. asas mandiri; dan i. asas seimbang. Asas dalam UU No. 22 Tahun 2009 dibuka kemungkinan untuk partisipasi dalam menyelenggarakan usaha angkutan,asas manfaat,asas efisien efektif,asas mandiri. Manfaat bagi pengguna jasa dan efisien efektif dalama tarif dan tujuan angkutan yang aman nyaman, mendapat perlindungan. Mandiri dalam hal penyedia jasa tidak harus korporasi atau badan hukum cukup orang perorang sebagai driver yang berkedudukan sebagai penyedia jasa langsung bagi pemakai jasa atau konsumen jasa angkutan online. ${ }^{22}$ Asas-asas tersebut dapat dijadikan dalam membuat perusahaan transportasi online, karena jika sudah memenuhi asas asas itu dan telah dilindungi oleh peraturan pemerintah maka setiap orang berhak menjadi pelaku transportasi online.

Pengertian persaingan usaha berdasarkan Undang-Undang Nomor 5 Tahun 1999 tentang Larangan Praktik Monopoli dan Persaingan Usaha Tidak Sehat ${ }^{23}$ yang mengatur tentang Larangan persaingan usaha tidak sehat dan praktik monopoli dalam pasal 1 angka 6 dijelaskan pengertian Persaingan usaha tidak sehat ialah persaingan antar para pelaku usaha dalam menjalankan kegiatan produksi dan atau pemasaran barang atau jasa yang dilakukan dengan melawan hukum atau menghambat persaingan usaha atau tidak jujur. Jadi persaingan usaha di bidang transportasi online ini tidak termasuk dalam jenis persaingan usaha tidak sehat. Karena mereka melakukannya dengan jujur dan tidak melaan aturan hukum yanga ada. Jika sudah diketahui bersama kalau transportasi online di Indonesia sudah di

${ }^{22}$ Agus Pribadiono, "Transportasi Online Vs Transportasi Tradisional Nononline Persaingan Tidak Sehat Aspek Pemanfaatan Aplikasi Oleh Penyelenggara Online”, Lex Jurnalica, Vol. 13 Nomor 2, Agustus 2016, h. 130-131.

${ }^{23}$ Lembaran Negara Republik Indonesia Tahun 1999 Nomor 3, Tambahan Lembaran Negara Republik Indonesia Nomor 3817, yang selanjutnya disingkat UU No. 5 tahun 1999 
akui keberadaannya dan sudah dilindungi oleh peraturan ppemerintah yang lebih kuat.

Model efisiensi dilakukan pengusaha transportasi online, akan tetapi dampak pendapatan yang signifikan antara pengusaha non online. Pertanyaany apakah pengusaha transportasi online melakukan persaingan usaha yang tidak sehat. Apabila melihat pengertian persaingan tidak sehat seperti yang termuat didalam UU No. 5 tahun 1999 yang membahas tentang larangan persaingan tidak sehat dan praktik monopoli bahwa yang termasuk unsur persaingan usaha tidak sehat yakni melakukan suatu kegiatan pemasaran atau produksi barang atau jasa yang dilakukan dengan melawan hukum atau tidak jujur atau memperlambat persaingan usaha.

Pengusaha transportasi online tidak dihambat untuk memasuki pasar transportasi online. Hal tersebut terbukti beberapa pengusaha transportasi online dapat masuk dalam kota besar bahkan daerah-daerah Kabupaten. Pembandingan persaingan antara sesama usaha transportasi online harus dibandingkan apel to aple tidak dengan usaha transportasi non-online. Pemanfaatan teknologi informasi guna untuk meningkatkan persaingan usaha dalam menjalankan usaha dan tidak dapat dihindari pemanfaatan informasi teknologi dalam rangka bersaing. Dengan melihat usaha transportasi online tersebut maka KPPU harus tegas dalam mengawasi persaingan antar perusahaan transportasi online tersebut.

Transportasi online dengan berbagai bentuk kemudahannya memang masih menyisakan masalah di bidang hukum. Transportasi online sering dianggap illegal karena belum jelasnya payung hukum pada sistem transportasi online ini. Permasalahan ini terjadi karena lambatnya respon pemerintah dalam merespon keberadaan transportasi online yang terus berkembang ini. Peraturan Menteri Perhubungan Nomor PM 16 Tahun 2019 tentang Perubahan Atas Peraturan Menteri Perhubungan Nomor PM 117 Tahun 2018 tentang Penyelenggaraan Angkutan Orang Tidak Dalam Trayek ${ }^{24}$ merupakan salah satu payung hukum yang dibuat pemerintah untuk transportasi online. Peraturan ini dibuat untuk mengatur jenis penyelenggaraan, pengusahaan, pelayanan angkutan umum menggunakan aplikasi berbasis online atau teknologi informasi, mengawasi angkutan umum dan juga

24 Berita Negara Republik Indonesia Tahun 2019 Nomor 310. Selanjutnya disingkat Permenhub Nomor 16 Tahun 2019. 
peran serta masyarakat dan sanksi adminstrasi. Pada saat ini Peraturan Menteri tersebut dirasa cukup mengakomodir segala pengaturan terkait transportasi online tersebut. Dengan adanya payung hukum ini maka seluruh pelaku bisnis transportasi online ini tidak lagi di bayang bayangi rasa takut akan ke legalan usaha yang di jalan raya. Para pelaku usaha di bidang transportasi online ini juga saling berebut konsumen dengan caranya sendiri sendiri. Akan tetapi perlu adanya kebijakan dari pemerintah selaku nahkoda dari Negara untuk membatasi penggunaan kendaraan berbasis online karena semakin banyak transportasi online yang beroperasi di jalan raya, maka tidak mentup kemungkinan

UU Nomor 22 Tahun 2009 mengatur antara lain penyelenggaraan Lalu Lintas Angkutan, pembinaan Lalu Lintas Angkutan Jalan, keharusan menyediakan angkutan umum, pengusahaan angkutan, dll. Apabila melihat pengertian tersebut, maka yang dimaksud dengan angkutan umum dalam Pasal 138 ayat (3) UU Nomor 22 Tahun 2009 telah dibahas tentang pengertian angkutan umum,dinyatakan bahwa angkutan umum barang dan atau orang hanya dapat dilakukan dengan kendaraan bermotor Umum. Kendaraan yang fungsinya pribadi atau plat hitam (sepeda motor, mobil penumpang, mobil barang) dengan menggunakan aplikasi online atau internet bukanlah termasuk dalam jenis angkutan umum sebagaimana yang termuat dalam UU No. 22 Tahun 2009. ${ }^{25}$

Banyaknya perusahaan dibidang transportasi online, maka Menteri Perhubungan membuat peraturan tentang tarif atas dan tarif bawah yang harus dibayar oleh konsumen. Terkait dengan penetapan pembatasan tarif bawah dan atas atas ojek online dari pemerintah atau Menteri Perhubungan, tidak adanya bentuk perlindungan hukum bagi pelaku usaha transportasi online yang diatur dalam Permenhub Nomor 16 Tahun 2019 berkaitan penyelenggaraan kegiatan taksi berbasis online. KPPU mendukung pemerintah dalam hal ini Kementerian Perhubungan, untuk menetapkan pengaturan yang dapat menjamin kesempatan berusaha yang sama bagi semua pelaku usaha penyedia jasa angkutan taksi, baik konvensional maupun online yang dikategorikan sebagai angkutan sewa khusus. KPPU dalam hal ini sebagai lembaga independen berhak mengusulkan kepada

\footnotetext{
${ }^{25}$ Endang Wahyusetyawati, "Dilema Pengaturan Transportasi Online”, RechtsVinding, tanpa Vol. Tahun. dan Hal. $\quad$ Diakses dalam file:///E:/KPPU/Teknologi\%20keuangan\%20digital/TRANSPORTASI\%20ONLINE_ENDANG.pdf
} 
pemerintah untuk menghapus kebijakan penetapan batas bawah tarif yang selama ini diberlakukan untuk taksi konvensional. Sebagai gantinya, wasit persaingan usaha ini menyarankan agar pemerintah mengatur penetapan batas atas tarif saja. Penetapan tarif batas bawah akan mengakibatkan ketidakefisiensian di industri jasa angkutan taksi secara keseluruhan, sehingga bermuara pada mahalnya tarif bagi konsumen. Tarif batas bawah juga menghambat inovasi untuk meningkatkan efisiensi industri jasa transportasi. Lebih jauh batas bawah tarif dapat menjadi sumber inflasi.

Regulasi batas atas dapat menjadi pelindung bagi konsumen dari proses eksploitasi pelaku usaha taksi yang strukturnya bersifat oligopoli. Selain itu, adanya batasan penetapan kuota atau jumlah armada transportasi baik online maupun konvensional beroperasi di suatu daerah dapat menghambat pelaku usaha untuk mengembangkan usahanya. Penentuan jumlah armada seharusnya diserahkan ke mekanisme pasar. Sehingga, pelaku usaha akan menyesuaikan jumlah armadanya sesuai kebutuhan konsumen. Pengaturan oleh pemerintah akan mengurangi persaingan dan pada akhirnya merugikan konsumen. Pengawasan KPPU terhadap administrasi izin operasional harus dilakukan. Adanya pengawasan ini akan menjaga kinerja operator transportasi konvensional dan operator transportasi berbasis aplikasi online untuk memenuhi standar pelayanan minimal yang juga harus dibuat terperinci oleh pemerintah. Kebijakan surat tanda nomor kendaraan (selanjutnya disingkat STNK) transportasi online yang diharuskan atas nama badan hukum dapat menghambat pelaku usaha perorangan. Pemerintah harusnya mengembangkan regulasi yang dapat mengakomodasi sistem Transportasi online dengan badan hukum koperasi yang asetnya dimiliki oleh anggota. Adanya STNK sebagai milik perseorangan, tapi dapat memenuhi seluruh kewajiban sebagai perusahaan jasa angkutan transportasi dalam naungan koperasi. Pengalihan STNK kendaraan pribadi menjadi koperasi tidak sejalan dengan prinsip gotong royong yang selama ini dibangun dan dianut oleh ekonomi Indonesia. Harusnya pola pengaturan STNK ini bisa memberikan ruang bagi masyarakat yang ingin berusaha dalam industri transportasi online. Untuk itu fungsi dan kewenangan KPPU dalam hal pengawasannya tetap harus dilakukan dengan sangat ketat, sehingga sesuai dengan regulasi yang mendukung persaingan usaha sehat. 


\section{KESIMPULAN}

Perlindungan hukum terhadap pelaku usaha harus dilakukan oleh Komisi Pengawas Persaingan Usaha harus dilakukan sesuai dengan perkembangan tekhnologi. Usaha Transportasi online adalah salah satu hasil perkembangan tekhnologi. Adanya usaha Transportasi online maka harus ada perlindungan terhadap pelaku usaha transportasi online. Perlindungan hukum terhadap pelaku usaha tersebut didominasi perusahaan unicorn. Perlindungan hukum terhadap pelaku usaha transportasi online harus diberikan oleh Komisi Pengawas Persaingan Usaha.

\section{SARAN}

Perlindungan hukum bagi pelaku transportasi online harus diberikan sebgai pelaksanaan keadilan. Untuk itu Komisi Pengawas Persaingan Usaha harus memberikan saran dan pertimbangan kepada pemerintah mengenai setiap kebijakan yang dikeluarkan pemerintah agar tidak terjadinya persaingan usaha yang tidak sehat dalam bidang transportasi yang dapat menghambat pertumbuhan ekonomi.

\section{DAFTAR BACAAN}

\section{Buku}

Asshidiqqie, Jimly, Pergeseran Kekuasaan Legislatif dan Eksekutif; Universitas Indonesia; 2000.

Fuady, Munir, Hukum Anti Monopoli Menyongsong Era Persaingan Sehat; Citra Adytia Bakti; Bandung, 2003.

, Hukum Anti Monopoli, Citra Aditya Bakti, Bandung, 2000.

Gordin, Robert E., Reason for Welfare; economic; Social and political but Ultimately Moral; Dalam Responsibility Right \& Welfare; the Theory of Welfare State;Westview Press Inc; Colorado; 1988.

Hadjon, Philipus M., Perlindungan Hukum Bagi Rakyat Indonesia, Bina Ilmu; Surabaya, 1987.

MD, Moh Mahfud, Demokrasi Dan Konstitusi Di Indonesia; Rineka Cipta; Jakarta, 2003.

Miro, Fidel, Perencanaan Transportasi untuk mahasiswa: perencana dan praktisi, Erlangga, Jakarta, 2005.

Rasyidi, Lili, Wyasa Putra; Hukum Sebagai Suatu Sistem; Cet II; Mandar Maju; Bandung, 2003. 
Sudarma, Putu, Implementasi Pengaturan Larangan Praktek Monopoli dan Persaingan Usaha Tidak Sehat, Disertasi tidak diterbitkan; Universitas Airlangga, Surabaya, 2000.

Wignjoseobroto, Soetandyo, Hukum; Paradigma; Metode dan Masalahnya; Cet I; Elsan \& Huma, Jakarta, 2002.

\section{Jurnal}

Adiwiyoto, Bambang, P, Konsep dasar Persaingan Usaha Tidak Sehat. Prosisding. 2005.

Harapan, Aria Dimas, "Hukum Dan Teknologi Suatu Kajian Teoritis Terhadap Penomena Layanan Transfortasi Online", Surya Kencana Dua: Dinamika Masalah Hukum dan Keadilan, Vol. 6 No. 1, Maret, 2016.

Hardiyanto, Muhammad Lutfi, Shalahudin Serba Bagus, Ahmad Munir, "Hak Politik Mantan Narapidana Untuk Mencalonkan Diri Sebagai Calon Kepala Daerah (Analisis terhadap Putusan MK. No. 42/PUU-XIII/2015)", Mimbar Yustitia, Vol. 1 No. 2, 2017.

Pratama, Geistiar Yoga, Suradi, Aminah, "Perlindungan Hukum Terhadap Data Pribadi Pengguna Jasa Transportasi Online Dari Tindakan Penyalahgunaan Pihak Penyedia Jasa Berdasarkan Undang-Undang Nomor 8 Tahun 1999 Tentang Perlindungan Konsumen”, Diponegoro Law Journal, Vol. 5, No. 3, 2016.

Prosiding UU No. 5/1999 dan KPPU. Catatan Diskusi konsep dasar Persainganusaha tidak sehat dan pendekatan rule of reason dan per se dalam hukum persaingan.Manan, Abdul, Aspek-Aspek Pengubah Hukum, Kencana, Jakarta, Cetakan ke-4, April, 2013.

Pribadiono, Agus, "Transportasi Online Vs Transportasi Tradisional Nononline Persaingan Tidak Sehat Aspek Pemanfaatan Aplikasi Oleh Penyelenggara Online", Lex Jurnalica, Vol. 13 Nomor 2, Agustus 2016.

Wahyusetyawati, Endang, "Dilema Pengaturan Transportasi Online", RechtsVinding, tanpa Vol. Tahun. dan Hal.

\section{Internet/ Media Online}

https://katadata.co.id/berita/2017/03/29/kppu-usulkan-tiga-poin-revisiaturan-taksionline.

https://ekbis.sindonews.com/read/1193460/34/kppu-tak-rekomendasikantarifbawah-taksi-online-1491048157 9. UUD 1945

https://today.line.me/id/pc/article/Respons+GO+JEK+Hingga+KPPU+Terhadap+T arif+Baru+Ojek+Online-qNxB52 3. 